\title{
DESPOLÍTICAS E DESOBEDIÊNCIAS: poéticas midiáticas de resistência a narrativas colonizadoras
}

\author{
IMPOLITIC AND DISOBEDIENCES: media poetics of resistance to \\ colonizing narratives
}

\section{DESPOLITIZACIONES Y DESOBEDIENCIAS: Poéticas de medios de comunicación de resistencia a las narrativas colonizadoras}

\section{Maria Thereza de Oliveira Azevedo ${ }^{1} \&$ Claudyanne de Almeida ${ }^{2}$}

\begin{abstract}
RESUMO: A proposta deste é artigo é refletir sobre despolíticas e desobediências de algumas poéticas midiáticas de resistência a narrativas colonizadoras. Serão observadas contranarrativas aos discursos da política brasileira que viralizaram nas redes sociais, a partir de criações populares como os memes. O objetivo é desvendar os modelos artificiais de representatividade (despolítica), homofobia velada e a colonialidade não percebida. A instrumentalização teórica do olhar para tais produções segue na perspectiva decolonial de Mignolo e Quijano com auxílio do conceito de estranhamento abordado por Brecht. Na possibilidade de construção de contranarrativas, que revisam a realidade, desconstroem e/ou reconstroem novas narrativas que desobedecem a discursos e à ordem necropolítica presente, norteamos esse texto.
\end{abstract}

\footnotetext{
${ }^{1}$ Maria Thereza de Oliveira Azevedo é Doutora em Artes Cênicas pela Universidade de São Paulo (USP) e Pesquisadora associada do Programa de Pós-Graduação em Estudos de Cultura Contemporânea - PPG ECCo da Universidade Federal de Mato Grosso (UFMT). Lidera o grupo de pesquisa Artes híbridas: intersecções, contaminações, transversalidades e o Coletivo à deriva. maritheaz@gmail.com.

${ }^{2}$ Claudyanne Rodrigues de Almeida é Doutoranda pelo Programa de pós graduação em Estudos de Cultura Contemporânea, na UFMT (Universidade Federal de Mato Grosso). Professora efetiva do IFMT (Instituto Federal de Educação, Ciência e Tecnologia de Mato Grosso). clauantropologiaearte@gmail.com.
} 
alavras-chave: Decolonialidade; Poéticas midiáticas de desobediência; Contranarrativas.

\begin{abstract}
The purpose of this article is to reflect on the impolitic and disobedience of some media poetics of resistance to colonizing narratives. Counter-narratives to the discourses of Brazilian politics that went viral on social networks will be observed, based on popular creations such as memes. The objective is to unveil the artificial models of representativeness (impolitic), veiled homophobia and unperceived coloniality. The theoretical instrumentalization of looking at such productions follows the decolonial perspective of Mignolo and Quijano with the help of the concept of strangeness, addressed by Brecht. In the possibility of constructing counter-narratives, which review reality, deconstruct and/or reconstruct new narratives that disobey speeches and the present necropolitical order, we guide this text.
\end{abstract}

Keywords: Decoloniality; Media poetics of disobedience; Counter-narratives.

Resumen: La propuesta de este artículo es reflejar sobre las despolitizaciones y desobediencias de algunas poéticas de medios de comunicación de resistencia en contra las narrativas colonizadoras. Serán observadas contranarrativas a los discursos de la política brasileña que se volvieron viral en las redes sociales, a partir de creaciones populares como los memes. El objetivo es desvendar los modelos artificiales de representatividad (despolitizada), homofobia velada y la colonización no percibida. La instrumentalización teórica de la mirada para tales producciones sigue la perspectiva de destrucción colonial de Mignolo e Quijano con la ayuda del concepto de extrañamiento, abordado por Brecht. En la posibilidad de construcción de contranarrativas, que repasan la realidad, deconstruyen y/o reconstruyen nuevas narrativas que desobedecen a discursos y al orden necropolítica presente, norteamos ese texto.

Palabras clave: Decolonialidad; Poéticas de medios de comunicación de desobediencia; Contranarrativas.

Diante da irracionalidade, do desespero da ordem atual, não seria evidente desobedecer? (GROS, 2018, p. 244)

\title{
NECROPOLÍTICA, decolonialidade e as redes sociais
}

O presente trabalho pretende apresentar discussões sobre as possibilidades de poéticas populares como construção de contranarrativas políticas a discursos e narrativas necropolíticas, ou o que podemos chamar de despolítica. A partir de autores e de teorias tais como necropolítica, decolonialidade, contranarrativa e estranhamento, pretende-se dialogar com exemplos de memes como poética midiática escolhida. Tais teorias propostas foram correlacionadas com o estudo de caso de discursos políticos específicos desconstruídos com memes produzidos 
sobre o tema. Suspeita-se que tais poéticas, despretensiosas ou não, criam campos de percepção e desmistificação de preconceitos e estruturas coloniais arraigadas na nossa cultura, se não tanto, ao menos desvendam tais estruturas de forma mais lúcida.

O recorte do período para seleção das produções visuais observadas é a partir do processo eleitoral no Brasil de 2018 - visto as considerações explicitadas pela efervescência de narrativas e contranarrativas com temática a ser pesquisada - até a continuidade do momento presente.

Os memes foram selecionados de acordo com a relevância do conteúdo com o objetivo do trabalho e de acordo com sua repercussão nas redes sociais sobre as narrativas relacionadas aos temas: gênero, minorias sociais, políticas neoliberais e patriotismo.

Aproximamo-nos dos autores e conceitos principais trabalhados, tais como: desobediência (Mignolo e Gros), necropolítica (Mbembe), estranhamento (Brecht) e contranarrativa, mas não nos atemos à sua trajetória histórica, apenas os elegemos para alargar nossos estudos e discussões sobre desobediência na poética midiática proposta, os memes.

$\mathrm{Na}$ conclusão do livro "Desobedecer", Frédéric Gros diz que numa democracia crítica a desobediência perpassa pela subjetividade política (2018 apud D'URSO, 2019, p. 257). A cena política contemporânea demanda olhares atentos e ativismo acadêmico. A ascensão e conquista de poder por partidos de extrema direita em vários países; ${ }^{3}$ a proliferação de discursos de ódio; as inúmeras vidas ceifadas de mulheres, indígenas, LGBTQIA+ e negros; as deliberadas perdas de direitos compõem o cenário político do tempo presente.

Produzir conhecimento sobre o contexto político no agora, por si, já se faz inadiável. Somado à ascensão do neoconservadorismo, em um clima de descrença na ciência, de censura aos corpos, desejos e amores em virtude de um ideal normativo que incita as existências anuladas e os silenciamentos forçados, o estudo torna-se urgência e desobediência pauta.

\footnotetext{
${ }^{3}$ Ver: CASIMIRO, Flávio Henrique Calheiros. A nova direita: aparelhos de ação política e ideológica no Brasil contemporâneo. São Paulo: Expressão Popular, 2018.
} 
O irracionalismo que permeia o presente, o uso da burocracia para a chacina ambiental e cultural, enquanto se vai "passando a boiada" na trilha da razão instrumental, essa que convenientemente coloca histórias de vida a escorrer pelas mãos lisas do obscurantismo por aí, "e daí", por aqui nos remete ao conceito de necropolítica do filósofo camaronês Achille Mbembe (2018). Para o autor, "a expressão máxima da soberania reside, em grande medida, no poder e na capacidade de ditar quem pode viver e quem deve morrer" (MBEMBE, 2018, p. 123). Dessa forma, a preocupação com traços do que Mbembe chamou de necropolítica no cenário sociopolítico contemporâneo clama por apontar o olhar para tais práticas e, principalmente, pensar formas de resistir a elas. Se essa resistência exigir contranarrativas, despolíticas e/ou desobediências, será um convite a desobedecer.

Mignolo (2008) argumenta em favor da opção descolonial como desobediência epistêmica. $\mathrm{O}$ autor afirma que descolonização, ou o que chamou de descolonialidade, significa ao mesmo tempo:

a) desvelar a lógica da colonialidade e da reprodução da matriz colonial do poder (que, é claro, significa uma economia capitalista); e b) desconectar-se dos efeitos totalitários das subjetividades e categorias de pensamento ocidentais (por exemplo, o bem sucedido e progressivo sujeito e prisioneiro cego do consumismo) (MIGNOLO, 2008, p. 313).

Assim, o objetivo deste trabalho é desvelar a lógica da colonialidade em alguns discursos e narrativas correntes na cena política contemporânea do Brasil. A observação se debruçará sobre criações virtuais populares como memes críticos a propósito dessas narrativas que chamamos aqui de poéticas ${ }^{4}$ midiáticas.

Memes são processos de comunicação mediados por tecnologia que gera sentidos e é embasada pelo discurso (BRASIL, 2017). As principais características dos memes são: imagem recortada, alterada ou descontextualizada

\footnotetext{
${ }^{4}$ Utilizamos o conceito de poéticas atribuído à palavra grega poiésis como modos de fazer, criação, formação, não só da arte clássica, mas de criação em geral. O próprio Mignolo (2010) critica a apropriação do termo estética na filosofia europeia que colonizou a etimologia da Aiesthesis, já que essa tinha o significado amplo de "sensação". Ademais, não temos pretensão de definir memes como arte ou não, apenas nos interessa a ação de criação popular em si e sua repercussão social. Na nossa percepção o termo poética, e não despoética, está mais próximo da estética decolonial, ou da decolonialidade da aiesthesis de Mignolo.
}

Cadernos de estudos culturais, Campo Grande, MS, v. 2, p. 185-208, jul./dez. 2020. 
da origem e função para qual foi criada; o texto interage com a imagem de forma que ele complementa ou dá um novo significado a ela. Utiliza-se, assim, da paródia e da sátira como recurso didático e comunicacional. ${ }^{5}$

De acordo com o guia disponibilizado no site SaferLab, que tem como proposta estimular a produção de contranarrativas para o discurso de ódio e discriminação on-line, "quando a gente fala sobre contranarrativas, falamos de histórias que se opõem ou desconstroem um senso predominante" (SAFERLAB, 2020, p. 2).

Contranarrativas para o discurso de ódio são maneiras de se opor e desconstruir narrativas comuns de discriminação e intolerância, mas vão além e têm uma abordagem propositiva, focando no diálogo, na igualdade, no respeito às diferenças e na liberdade. Isso pode ser feito com fatos, dados, humor, sensibilidade, humanidade e experiências que possibilitem experimentar diferentes pontos de vista. Provocar empatia é um dos objetivos. (SAFERLAB, 2020, p. 2)

São múltiplas as influências das redes sociais nas ideologias que compõem o cenário contemporâneo. Ampliam vertiginosamente e ocupam espaços inimagináveis. Nesse ínterim, produções visuais e artísticas, as poéticas midiáticas, sobre temas políticos se avolumam. De acordo com Ricardo Sékula (2016), hoje, temos a incidência cada vez maior do debate público em microesferas virtuais de discussão, produções colaborativas e remixagens, o que demarca uma dimensão estética, com capacidades técnicas e expressivas de se apropriar e ressignificar os discursos do outro ou de si. A chegada da internet e das redes sociais modificou os contatos sociais, a forma de se relacionar com o outro e consigo. Nos tempos do agora, muitas vezes, fica-se sabendo de determinado fato por meio de um meme, antes mesmo de se ter acesso à fonte oficial de informação. Comenta-se a vida, por vezes, a partir de um episódio de série ou da performance de artistas, youtubers, influenciadores digitais, num canal ou numa live. A própria TV perdeu espaço como fonte de informação, segundo a última pesquisa brasileira de mídia (PBM), realizada pelo Ibope Inteligência em

\footnotetext{
${ }^{5}$ Os memes tratam sempre de um tema muito atual, possuem linguagem fácil geralmente, podendo atingir um público extenso e se introjetam espontaneamente na comunicação e nas conversas informais em geral. Têm na composição fragmentos de distintas citações que se autorreferem e constroem uma narrativa outra, de maneira que sua poética de desconstrução, reelaboração e ressignificação de narrativas pode ser olhada como uma forma de desobediência a narrativas hegemônicas.
} 
$2016^{6}, 49 \%$ das pessoas se informam pela internet. Considerando que essa pesquisa foi realizada em 2016, possivelmente esse número já aumentou. Como mostram os dados do mais importante estudo sobre consumo de notícias do mundo, o Digital News Report, do Reuters Institute, ${ }^{7} 64 \%$ dos brasileiros que têm acesso à internet se informam por meio das redes sociais. Somado à leitura de notícias on-line, esse número chega a $87 \%$. Podemos ver até mesmo um movimento inverso em relação à $\mathrm{TV}$ e redes sociais que antes repercutiam o mundo da TV: hoje muitos jornais televisivos repercutem vídeos que viralizaram nas redes ou as palavras e memes mais curtidos e compartilhados no Twitter ou Instagram.

As produções culturais midiáticas constituem-se como instâncias que conformam e produzem representações de mundo (...), (re)produzindo, (re)organizando e (re)inventando novas relações para elas. (...) Esse processo de instauração de significados não decorre, apenas, de uma particular enunciação colocada em destaque, mas de muitas e intrincadas interações postas em ação pelos/as leitores/as, suas experiências anteriores e o texto em questão. (FOERSTE; CAMARGO, 2010, p. 2059)

Ninguém é obrigado a ser um avatar ou participar necessariamente de uma rede social, mas é fato que essa pessoa inevitavelmente deixa de partilhar movimentos do mundo atual que faz parte do imaginário social. É quase como se não falasse a língua universal. As redes sociais podem ser vistas como a nova língua, com cosmologia própria, participando ou não delas. Assim, para pensar a produção de narrativas e de contranarrativas na política contemporânea, faz-se essencial refletir sobre as poéticas midiáticas. mediático:

Para Quijano (2002, p. 6) a globalização se associa agora a um novo habitat

A "realidade virtual" (...) tem implicações decisivas no debate sobre a produção do conhecimento. Põe em relevo, sobretudo, que com a tecnologia atual já não se reproduz apenas, se combina ou se usa imagens e sons já presentes na "natureza" ou na "realidade", mas se produz, manipula e difunde novos elementos visuais e

6 Disponível em: http://www.secom.gov.br/atuacao/pesquisa/lista-de-pesquisas-quantitativas-equalitativas-de-contratos-atuais/pesquisa-brasileira-de-midia-pbm-2016.pdf/view - acesso em: 12 jun. 2020).

7 Disponível em: https://reutersinstitute.politics.ox.ac.uk/sites/default/files/201906/DNR_2019_FINAL_0.pdf_- acesso em: 12 jun. 2020).

Cadernos de estudos culturais, Campo Grande, MS, v. 2, p. 185-208, jul./dez. 2020. 
sonoros, novas imagens produzidas com tais novos elementos que em seu conjunto já constituem um mundo "virtual" e que de muitos modos se superpõem e ainda deslocam e substituem o mundo "real" (...), com tudo que isso significaria para a questão da percepção, do conhecimento e do modo de produzir conhecimento. A "sociedade virtual" é uma ideia que prolonga essa imagem e propõe que as relações sociais ocorrem, cada vez mais, precisamente dentro de e tramadas com aquela "realidade virtual" e de algum modo tem essa consistência.

\section{DESOBEDECER, desviar, deslocar: questões de gênero}

Neste novo milênio, vivemos um momento político ímpar no Brasil. A eleição para presidente do país do primeiro operário e da primeira mulher. A mesma década que marcou grandes conquistas marcou também a deposição dessa primeira presidenta mulher em meio a crescentes discursos de ódio e perda de direitos. Junto a isso, surgiram as narrativas e ações no sentido do desmonte do bem-estar social, de políticas e serviços públicos, como sugerido na cartilha neoliberal do Consenso de Washington.

Neste cenário, temas da vida privada ganharam destaque na opinião pública com viés de legislar a vida privada e amordaçar palavras a partir de temas considerados "malditos", alvos de censuras e profanações. Percebe-se que entre os principais temas estão as pautas dos estudos de gênero, chamadas de "ideologia de gênero" pela massa induzida ao medo. Como um mote de uma suposta ideologia que destrói a família nuclear, em sua estrutura secular, assim como a inocência das crianças, os setores da sociedade civil e o setor governamental, inspirados em princípios moralistas e fundamentalistas religiosos que lhes interessam, organizam-se em torno de pautas proibitivas e criminalizantes desse debate na vida social. Consequentemente acabam por tentar rechaçar e banir a possibilidade de existências que não estejam alinhadas à heteronormatividade, e demarcando o binarismo de gênero como a única identidade inteligível e reconhecível, constitutivo de uma "natureza humana" e de um ideal de vida. Delimitam, assim, o que são vidas dignas de serem vividas e as que não o são. Cenário propício da necropolítica (MBEMBE, 2018), tais narrativas questionam ainda os avanços com relação aos direitos das mulheres, dos negros, indígenas e todo grupo considerado conceitualmente como minorias sociais. Observamos que tais ações e narrativas remetem diretamente ao discurso colonizador. Como demarca Mignolo (2008, 289),

Cadernos de estudos culturais, Campo Grande, MS, v. 2, p. 185-208, jul./dez. 2020. 
O controle da política de identidade reside, principalmente, na construção de uma identidade que não se parece como tal, mas como a aparência "natural" do mundo. Ou seja, ser branco, heterossexual e do sexo masculino são as principais características de uma política de identidade que denota identidades tanto similares quanto opostas como essencialistas e fundamentalistas.

A partir dessa elucidação, Gabriela Souza (2019), num artigo sobre a colonialidade dos discursos de políticos, trouxe-nos algumas falas da atual Ministra da Mulher, da Família e dos Direitos Humanos:

Atenção: uma nova era chegou no Brasil. Meninos vestem azul e meninas vestem rosa (Vídeo em redes sociais, janeiro de 2019).

Nesse governo, menina será princesa e menino será príncipe. Ninguém vai nos impedir de chamar nossas meninas de princesa e nossos meninos de príncipe. Vamos acabar com o abuso da doutrinação ideológica. (Discurso de posse em Brasília, janeiro de 2019).

Eu critico é a tentativa de interferência dos ideólogos de gênero na identidade de nossas crianças (Post no Instagram, maio de 2019).

Esses discursos provocaram nas redes sociais uma enxurrada de reações em forma de memes, charges, hashtags, ou seja, criações/poéticas populares que desobedeciam ao poder instituído a um cargo do ministério de um país. Apresenta-se o que chamaremos de despolítica, contranarrativas que desobedecem a uma narrativa hegemônica ou que detêm o poder do momento, criando, assim, imagens de ocupação de espaços por meio do discurso no contrafluxo que poderia contagiar as narrativas de subjetividades vigentes. Tais como: 

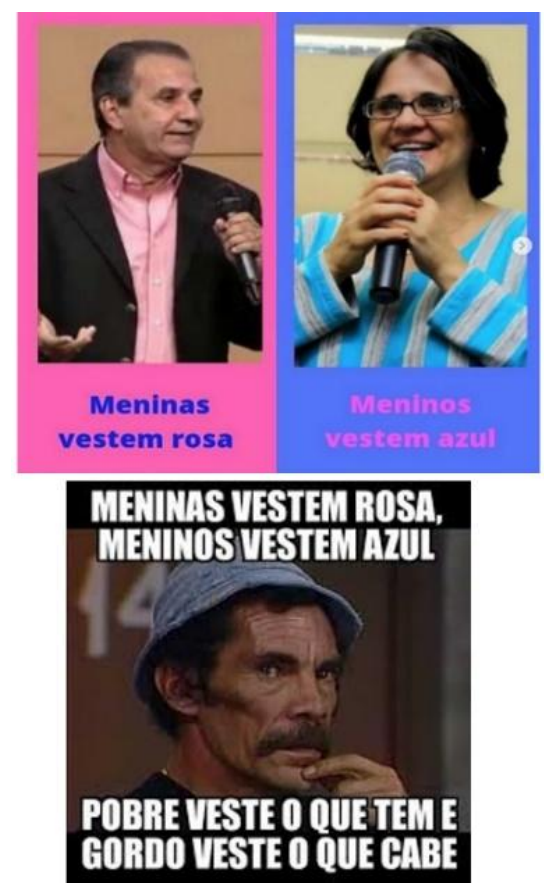

General Mourão é o primeiro Vice Presidente casado com um menino!
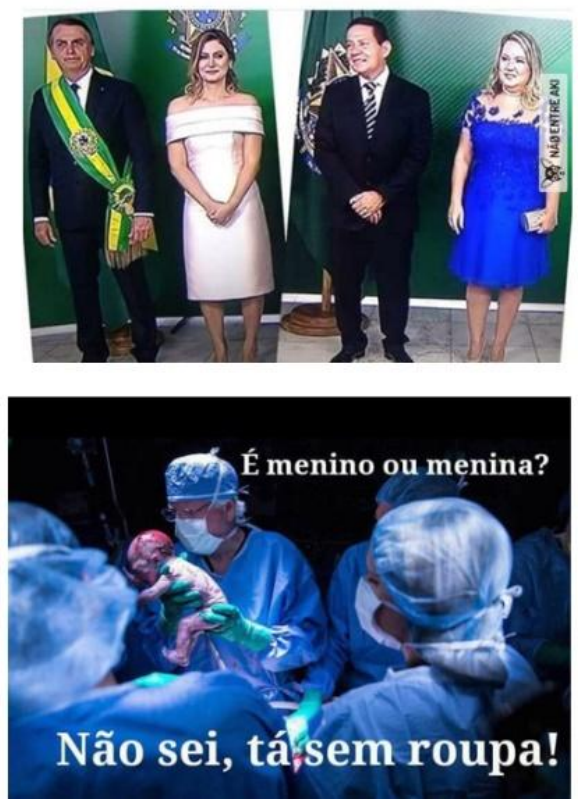

FIGURA 1 -Memes Damares.

FONTE: Elaborado pela autora com imagens selecionadas do site Google.

Tais poéticas midiáticas populares disputam espaço na construção de narrativas de forma descontraída, não apelativa, desviando dos canais oficiais de poder, de política institucional, por isso as consideramos despolítica. A ideia mais próxima a despolítica estaria justamente nas teorias decoloniais quando Mignolo (2008) clama por construir nova forma de política e não lutar pelo controle da política de Estado que temos, ou seja, quando clama por "desfetichizar o poder". 8

Encontramos o traço decolonial também nessa característica de desvio, deslocamento desses canais oficiais e da narrativa hegemônica. Esse desobedecer com desvios acaba por ser uma estratégia poética de resistência. De acordo com

\footnotetext{
8 "Desfetichização do poder político em uma organização econômica que visa à reprodução da vida ao invés da reprodução da morte e visa à reciprocidade e à distribuição justa da riqueza entre muitos, e não à acumulação de riqueza entre poucos." (MIGNOLO, 2008, p. 298).
} 
Pereira (2017, p. 20), "em contextos pós-coloniais, de sociedades que foram colonizadas $(\ldots)$, resistir apresenta-se como descolonizar".

Resistir é desviar(-se) para não ter que se chocar sempre contra um poder, uma força maior. (...) Resistir é deslocar(-se) de tal modo que se possa fugir, criar linhas de fuga (DELEUZE e GUATTARI, 1995), ocupar outros lugares, reposicionar-se. Toda forma de resistência implica em alguma forma de deslocamento, desvio. (PEREIRA, 2017, p. 18)

$\mathrm{O}$ traço decolonial desses memes críticos também está no tema em si que desobedece à narrativa que desconsidera as diversidades, enquadrando-se no mundo "UNI-versal" que tanto buscou/busca a colonialidade do poder. Ao delimitar o lugar de ser homem e ser mulher no país, exclui as identidades dissidentes por uma cosmologia universalizada, padronizada. Os memes críticos são pluri-versais, à medida que buscam descolonizar a naturalização sobre o olhar para a pluralidade do cotidiano universalizado pela "colonialidade do poder, do saber, do ser" e do sentir.

A cosmologia ocidental é "uni-versal" (em suas diferenças) e imperial enquanto o pensamento e as epistemologias descoloniais tiveram que ser pluri-versais: aquilo que as línguas e as cosmologias não ocidentais tinham em comum é terem sido forçadas a lidar com a cosmologia ocidental. (MIGNOLO, 2008, p. 316)

Os memes críticos ridicularizam e desconstroem as narrativas conservadoras usando até mesmo os atores da própria narrativa, como no primeiro e segundo memes. Ou mesmo aprofundam o olhar sobre a superficialidade da narrativa, como no terceiro. Corrobora a desconstrução mitigada por Mignolo o fato de que o controle da política de identidade está na naturalização do mundo tal qual o do colonizador, branco, heterossexual, com o binarismo de gênero inabalável, demarcando o critério de distinção ou identificação essencialista.

\footnotetext{
${ }^{9}$ Tanto esse autor como Mignolo nesses textos ainda utilizavam o termo “descolonizar", porém, há atualmente um grande movimento de readequação desse termo para a palavra "decolonizar" ou "decolonialidade", visto que os autores do giro decolonial refletiram que não é possível descolonizar a história, não se tira a colonialidade, é possível resistir, reler por outros ângulos a construção da colonialidade e, a partir dela, reelaborar e exaltar o lugar dos corpos colonizados na contemporaneidade. Por isso, o termo "decolonialidade" se tornou mais adequado e mais utilizado. Ainda sobre os termos "decolonizar" e "descolonizar", o primeiro está intimamente relacionado aos estudos do grupo modernidade/colonialidade e à superação dos padrões de poder da colonialidade, enquanto o segundo está mais relacionado à superação do colonialismo.
}

Cadernos de estudos culturais, Campo Grande, MS, v. 2, p. 185-208, jul./dez. 2020. 
Ao observar o papel do discurso baseado na colonialidade do poder, é possível desvendar as artificialidades na representatividade desses discursos. A maioria das pessoas que repete esses discursos e acredita na mal-afamada "ideologia de gênero" desconhece que os estudos acadêmicos sobre gênero contribuem para sua própria autonomia, para o direito da mulher de poder trabalhar, vestir calças, casar com quem quer ou descasar de quem não quer; as crianças poderem se expressar; os homens serem desobrigados das inúmeras pressões empunhadas sobre fortaleza, choro ou ser provedor etc. A narrativa da Ministra, na sua literalidade, não representa a maioria da população brasileira, que veste na criança a roupa que ganhou de uma doação da igreja, de um parente mais velho ou de um primo que foi assassinado pela política de extermínio (vide reflexões do meme com Sr. Madruga). Definir padrões de cor vai além do que se veste, é uma violência simbólica para diversos corpos que não se encaixam no corpo uni-versal, tortura os multi-versos, define obrigações morais, reprime expressões de sentimentos, palavras e gestos do ser humano. Obrigar a enquadrarse e se moldar no UNI-VERSAL abre feridas em muitos corpos e almas, o que imaginamos não ser o desejo das pessoas que seguem essa narrativa, já que torturar, matar, violentar vai contra os princípios do eixo religioso aos quais se enquadram (cristão, o eixo do colonizador, diga-se de passagem). Desse modo, não alcança representatividade nem mesmo no eixo conservador em sua essencialidade. Demonstra, assim, que o que está por trás dessa narrativa colonialista e neoconservadora não refletida é a LGBTfobia+ velada, pura e nada simples.

Tais discursos vêm de uma ancestralidade colonialista, paternalista e patriarcal. Lembrando que princesas e príncipes não existiam no Brasil até a invasão dos colonizadores.

$\mathrm{O}$ uso do humor em tais produções de memes se aproxima do público em geral, além de ser criado pela própria população, e não por especialistas ou pela academia. A desobediência de alguns memes contém argumentos de desconstrução da narrativa mítica, odiosa, por isso pode ter efeito pedagógico. $\mathrm{O}$ processo de desconstrução traz uma nova compreensão daquela narrativa, ressignificando-a.

\section{MINORIAS SOCIAIS, somos todos iguais?}


E se a lógica da colonialidade está em: esquemas cristalizados de unidade, pureza e autenticidade, capitalismo, formação de Estado, educação de universidade, informação e mídia como mercadoria, "nivelando o mundo" (MIGNOLO, 2008), trazemos outra poética midiática popular que viralizou nas redes também em contraposição a tais discursos colonialistas, muito comuns no drama político contemporâneo - A Barbie Fascista, também chamada de Barbie do bem, Barbie Militante, Barbie antropóloga, Barbie e Ken cidadãos do bem ou Barbie Fascionista. "No Brasil, a Barbie vota para a extrema-direita" é a manchete de uma matéria publicada pelo jornal francês Le Monde em 24/10/2018. O jornal explica que os memes da boneca Barbie têm viralizado nas redes sociais, representando a elite branca brasileira e tornando a personagem "a caricatura do eleitor de Jair Bolsonaro. (...) As redes sociais foram inundadas por memes representando as brasileiras loiras, magras, com dentes brancos e seios empinados (...), destaca a matéria.". 10

Tais memes reproduzem falas literais muito comuns nas narrativas de brasileiras e brasileiros, políticos ou não, principalmente a partir da disputa eleitoral de 2018.

Alguns exemplos:
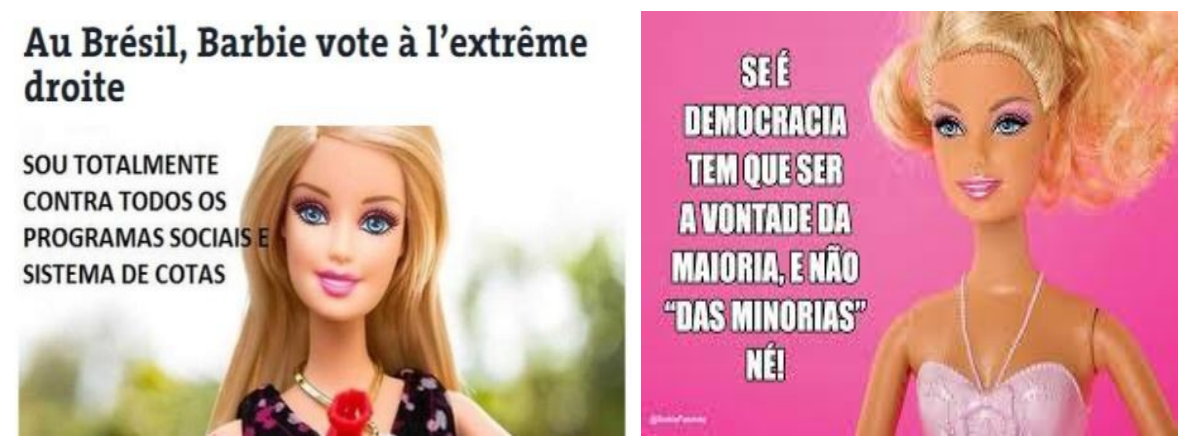

\footnotetext{
10 Disponível em: https://domtotal.com/noticia/1304213/2018/10/no-brasil-a-barbie-vota-para-aextrema-direita-mancheta-le-monde-sobre-eleicoes/ - acesso em: dez. 2018.
} 
Estudo que nem uma desgraçada e as cotas só favorecem as pessoas de baixa renda, somos todos iguais.
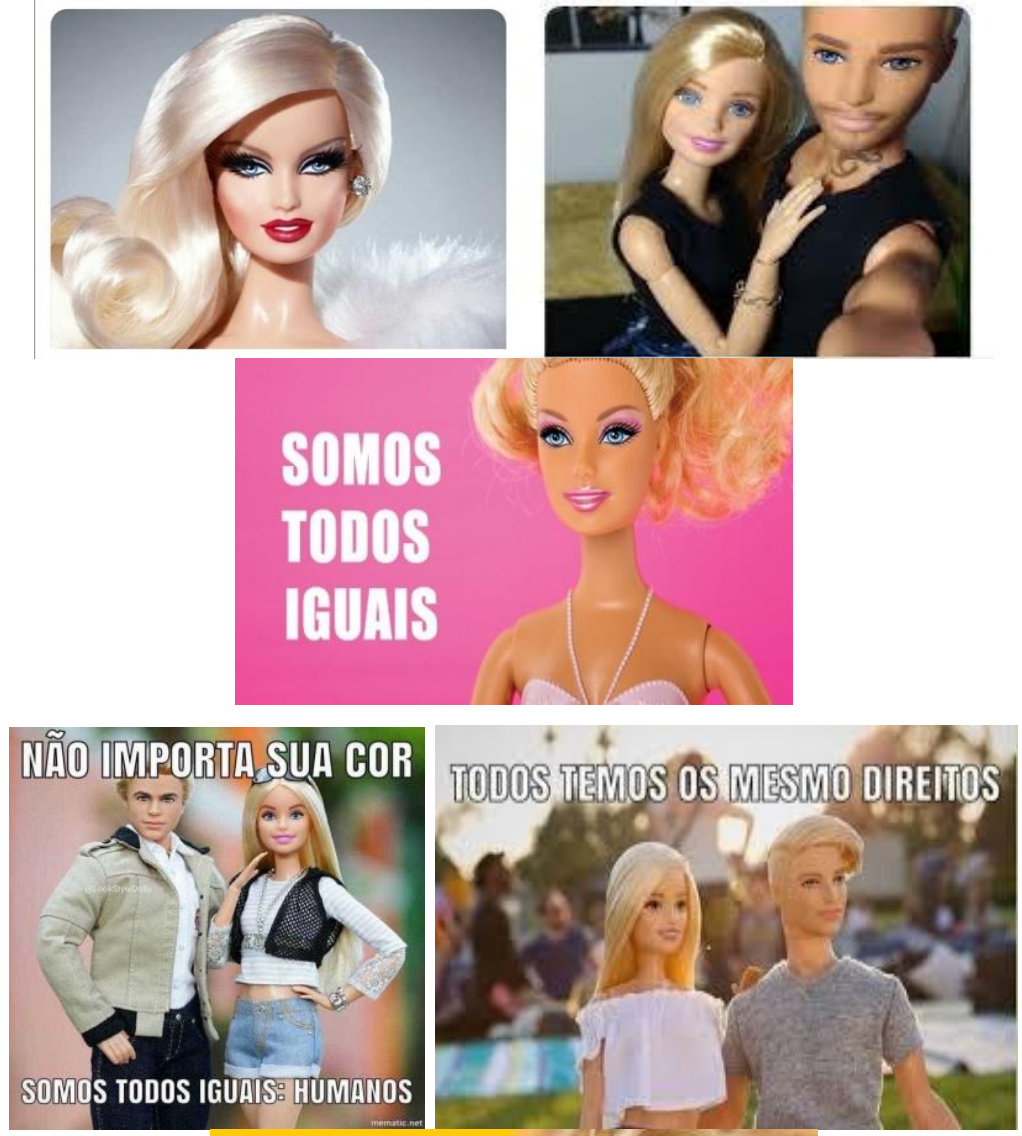

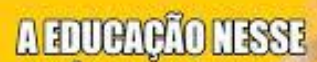

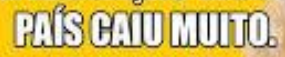

(1) IIIDDOA

SOBORROLTER

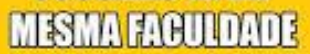

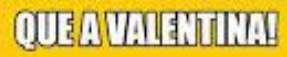

não importa se vc é gay, negro ou pobre...no fundo somos todos iguais!!! \#elesim \#b17 \#mudabrasil

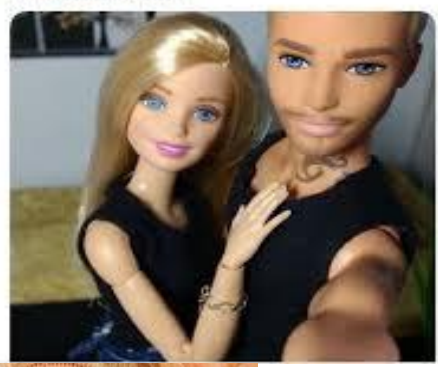

Cadernos de estudos culturais, Campo Grande, MS, v. 2, p. 185-208, jul./dez. 2020. 
FIGURA 2 -Memes Barbie Fascista

FONTE: Elaborado pela autora com imagens selecionadas do site Google

A frase "Somos todos iguais", pronunciada pelo estereótipo do padrão colonizador: branca, magra (de medidas hiper-reais), loira, olhos claros causa estranhamento até mesmo para os que pronunciam essa frase cotidianamente. Desconfiamos. Tanto os discursos da ministra da Mulher, da Família e dos Direitos Humanos, quanto as narrativas exemplificadas por esses memes da Barbie fascista, não só negam a diversidade, mas desvelam o desprezo por ela. De acordo com Mignolo, "a defesa da similaridade humana sobre as diferenças humanas é sempre uma reivindicação feita pela posição privilegiada da política de identidade no poder" (MIGNOLO, 2008, p. 300). Assim como o termo "etnia" ou "grupos étnicos", já que étnico são os considerados diferentes dos que estão no poder, ${ }^{11}$ com grupos identitários, a referência é sempre quem está no poder/quem o detém.

A inferiorização e negação dos direitos e do poder das minorias sociais, de acordo com Umberto Eco (2018), são algumas das faces do fascismo. Na fatídica reunião ministerial de 22 de abril de 2020, no palácio do planalto do Brasil, o então Ministro da Educação, Abraham Weintraub, disse uma frase interessante de ser analisada: "Só tem um povo nesse país. Quer, quer. Não quer, sai de ré", 12 remetendo diretamente às propagandas do governo ditatorial no período militar, como o slogan: "Brasil, ame-o ou deixe-o". Frase ainda mais interessante para se refletir sobre a necessidade de desobediência epistêmica, e que remete aos memes da Barbie fascista, foi a seguinte: "Odeio o termo povos indígenas, povos ciganos, somos um povo só" (grifo nosso). O atual presidente também foi capaz de pronunciar a seguinte frase: "Cada vez mais, o índio é um ser humano igual a nós" (transmissão em live do seu canal, no dia 24/1/2020). ${ }^{13}$ O povo e o "nós" devendo seguir o modelo cultural dos autores do discurso: capitalista, consumista,

${ }^{11}$ Exemplo: A maioria da população na África do Sul é negra, porém, os considerados étnicos eram eles, os nativos, pois quem estava no poder eram os brancos ingleses, que não representavam nem $1 \%$ da população, mas detinham o poder do Estado.

12 Disponível em: https://noticias.uol.com.br/politica/ultimas-noticias/2020/05/22/weintraubodeio-o-termo-povos-indigenas-quer-quer-nao-quer-sai-de-re.htm - acesso em: 10 jun. 2020.

13 Disponível em:https://g1.globo.com/politica/noticia/2020/01/24/cada-vez-mais-o-indio-e-umser-humano-igual-a-nos-diz-bolsonaro-em-transmissao-nas-redes-sociais.ghtml - acesso em: 10 jun. 2020.

Cadernos de estudos culturais, Campo Grande, MS, v. 2, p. 185-208, jul./dez. 2020. 
colonial, dando a entender que, assim não sendo, podem ser excluídos: "quer quer, não quer, sai de ré", como complementou Weintraub. Um desejo intrínseco que mescla a eugenia, a eliminação e o etnocentrismo próprios do colonizador. A reação a tais citações demonstrou que são discursos tanto de uma ala política quanto de parte significativa da população. Rememoramos, assim, Frédéric Gros: "Diante da irracionalidade, do desespero da ordem atual, não seria evidente desobedecer?” (2018, p. 244 apud D’URSA, 2019, p. 257).

Mas o fato é que a frase "Somos todos iguais" em um meme com uma imagem que representa o padrão colonizador, por meio de uma boneca conhecida por ser brinquedo nas mãos da elite burguesa, desloca a imagem e a frase do seu lugar de origem e traz outra sensação ao leitor. A paródia da Barbie Fascista traz uma contranarrativa de espelho, a partir do humor, da sátira ácida que ganha outra simbologia no meme, para além de ouvir um político emitir a narrativa. Ela desconstrói a narrativa à medida que confronta o sujeito falante. Motiva a sensação de pertencimento à narrativa, ao mesmo tempo a repulsa ao desejar não pertencer ao sentido que lhe foi atribuído.

O escritor argentino Ricardo Piglia (apud GOMES, 2011) reflete sobre as contranarrativas a partir da margem, dos subúrbios do mundo, pontuando que desse lugar existe um limite para conseguir se representar a partir da linguagem. Falar da violência, da corrupção, do fascismo, etc. de forma a fazer o outro sentir o que ele quer dizer, existe um limite. Dessa maneira, ele cria uma estratégia de "deslocamento":

Atribuir a outro uma cena que condensa e cristaliza uma rede múltipla de sentido, indo além da mera informação, uma vez que é um movimento interno ao relato, que desloca para o outro a verdade da história, verdade que tem a estrutura de uma ficção onde outro fala, isto é, propõe-se construir na linguagem um lugar para que o outro possa falar" (GOMES, 2011, p. 14)

A representação artística parece ter essa potência. No caso, a contranarrativa formatada em paródias de humor que são tidas como bobas e superficiais, como os memes, parece carregar essa estratégia de deslocamento e desobediência. "Requer, então, o deslocamento da observação direta da realidade, para reivindicar a sugestão, mediada por outro, por outras imagens, para se contrapor às ficções oficiais, as ficções do Estado burguês: as narrativas contra hegemônicas que fazem frente às narrativas hegemônicas (GOMES, 2011, p. 15). Como já dito, mas convém reforçar, deslocamento é não apenas uma técnica decolonial, como uma estratégia de resistência (PEREIRA, 2017).

Cadernos de estudos culturais, Campo Grande, MS, v. 2, p. 185-208, jul./dez. 2020. 


\section{CONTRANARRATIVAS, "livre mercado" e patriotismo}

"Meu pai disse que não sofreu na ditadura. Naquela época o Brasil era melhor."

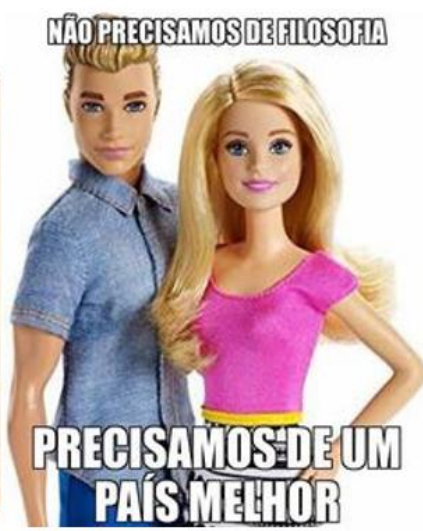

Vocês vão ter que dormir com o choro entalado, petralhada. A nova era

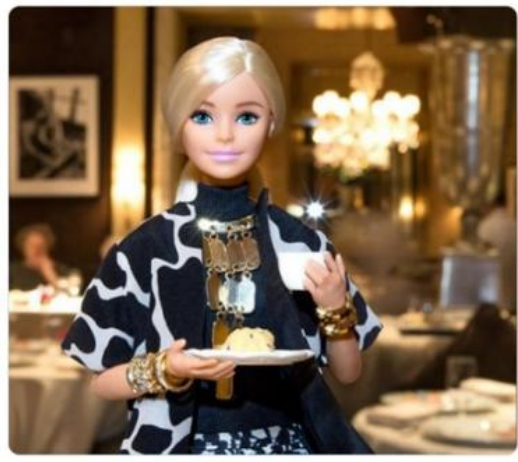
começou! Brasil acima de tudo, Deus acima de todos

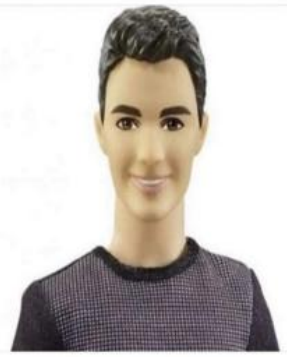

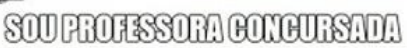

bom dia amores!!!! hj é dia de lutar por um país melhor e mais justo, sem esse câncer chamado PT que destruiu nosso brasil. \#PTnuncamais \#EleSim \#B17
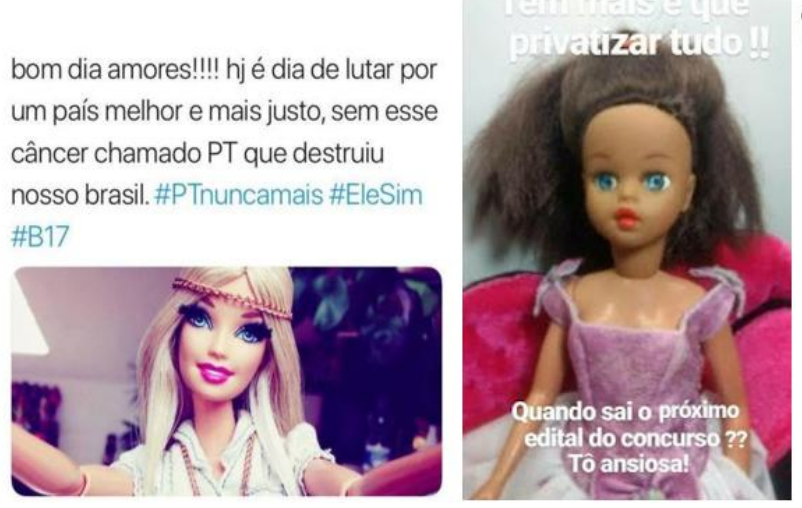

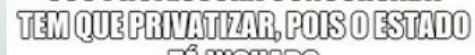

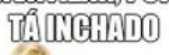

FIGURA 3 - Memes "livre mercado" e patriotismo.

FONTE: Elaborado pela autora com imagens selecionadas do site Google.

A respeito de discursos neoliberais e de patriotismo, as teorias de Aníbal Quijano (2002) refletidas aqui desconstroem a suposta representatividade na ideia meritocrática da "nova economia virtual" ou a globalização do capital do projeto neoliberal. Esse projeto político, pressionado por países ricos, constrói uma cartilha para países dependentes seguirem, segundo a qual uma das principais características é a privatização da economia, da vida e do conhecimento (colonialidade do poder, do ser, do saber). De acordo com Quijano (2002, p. 9), a dominação e a exploração no atual padrão de poder são "encobertas por estruturas 
institucionalizadas de autoridade coletiva ou pública e 'legitimadas' por ideologias constitutivas das relações intersubjetivas".

A suposta fantasia de patriotismo, nacionalismo acima de tudo, bradada em ufanismos pagos em dólar por uma camiseta oficial do time masculino da Seleção Brasileira de futebol, não encontra representatividade no modelo econômico neoliberal que os manequins da tal camiseta também defendem paradoxalmente. À medida que os países precisam seguir o padrão (sistema-mundo-modernocolonial) (QUIJANO, 2005) tendo que se enquadrar aos modelos neoliberais como matriz política, econômica e moral, percebe-se uma erosão da soberania desse país, do povo, e consequentemente a "desdemocratização" da sociedade. Da representação da sociedade no Estado, o que provoca a "desnacionalização da sociedade no Estado" (QUIJANO, 2002, p. 12). Erosão contínua do espaço nacional-democrático, desnacionalização, desdemocratização e subserviência estão por trás dos discursos que esses memes da Barbie fascista criticam e desobedecem.

A trama institucional imperial formada por tais Estados-nação, as entidades intergovernamentais de controle e exercício da violência, como a Otan, as entidades intergovernamentais e privadas de controle do fluxo mundial de capital, financeiro (...) e as grandes corporações globais. Essa trama já constitui, de fato, um tipo de governo mundial invisível. (...) Esses Estados locais estão sendo, uns, convertidos em estruturas institucionais de administração local de tais interesses mundiais (...) ou como a tecnocracia administradora das entidades financeiras e das políticas econômicas dos Estados, inclusive ao se tratar de entidades supostamente públicas, como as instituições intergovernamentais do capital financeiro, o FMI ou o que se conhece como o Banco Mundial. (QUIJANO, 2002, p. 11).

\section{ESTRANHAMENTO, arte e desobediência nos memes}

Para potencializar a discussão, passamos a olhar os exemplos de memes apresentados em tensão criativa com os contornos do conceito brechtiano de estranhamento.

A palavra Ostraniene, utilizada originalmente como neologismo por Viktor Chklovski em 1917 no livro Poetika, significava o efeito de distanciamento do modo comum, de obscurecer a forma, aumentar a dificuldade e duração da percepção, que pode ser proporcionado pela arte (FOERSTE; CAMARGO, 2010, p. 2058). 
O método do dramaturgo alemão Bertolt Brecht utiliza o teatro como recurso didático para conhecimento a partir do estranhamento, da desfamiliarização. Em sua práxis teatral, Brecht (apud RODRIGUES, 2010, p. 54) "criou técnicas que tencionam provocar no espectador essas duas reações, a de surpresa e a de estranheza, a fim de produzir o distanciamento". De acordo com Brecht, "estranhar um processo ou caráter significa inicialmente retirar desse processo ou caráter aquilo que é evidente, conhecido, manifesto, e provocar espanto e curiosidade diante dele" (BRECHT, apud KOUDELA, 2010, p. 32). Sua técnica permitia o espectador refletir sobre seu lugar na sociedade.

Ainda a respeito desse conceito, em Lukács o estranhamento recebe o caráter histórico-social em todas as relações sociais, econômicas e políticas, compreendido assim como antítese-dialética das relações de produção. $\mathrm{O}$ estranhamento então gera o reflexo dialético da realidade pela sensibilidade em "reconhecer-se, reencontrar-se, reelaborar-se olhando por detrás da construção social" (apud FOERSTE; CAMARGO, 2010, p. 2058).

A pesquisadora Natássia Oliveira (2010) reflete acerca de uma experiência sobre a peça Ateliê voador para uma disciplina no curso de Artes Cênicas que apresenta patrões e trabalhadores. Os últimos, eles mesmos compram e consomem tudo que produzem como clientes e ganham em grãos, assim como os pássaros engaiolados. Diz que na primeira leitura da peça a atmosfera foi de total estranhamento. $\mathrm{O}$ conteúdo absurdo sob a forma absurda contesta o riso que não cessa. Não há nada muito engraçado na situação em que se passa, mas a ironia é o ponto forte da escrita (2010, n.p., grifo nosso). Assim como os memes, a ironia leva ao riso que, com o passar do tempo, a percepção pode ela mesma constranger esse riso pela brutalidade do significado da frase aparentemente tola.

Meu pai disse que o regime militar só matou bandido ou Meu pai disse que não sofreu na ditadura, naquela época o Brasil era melhor são frases comuns nas redes sociais de muitos brasileiros, mas o fato de ser uma boneca Barbie pronunciando-as - novamente uma boneca branca, de aparência aristocrática e representante de todos os estereótipos de não bandido, não vilã, tomando um chá das cinco (cultura europeia) - desloca a narrativa para outra esfera. Provoca estranhamento, distancia do discurso naturalizado, desnaturaliza a narrativa.

Além disso, se para Lucáks o estranhamento pode traduzir curiosidade e/ou repúdio (FOERSTE; CAMARGO, 2010, 2057), ao reler tal frase numa construção imagética, poderia levar o repetidor à curiosidade de uma breve pesquisa. E, nesse

Cadernos de estudos culturais, Campo Grande, MS, v. 2, p. 185-208, jul./dez. 2020. 
processo, perceber que tem um amigo religioso, um tio cantor, artista, que num regime militar possivelmente seria reprimido, exilado ou até torturado, de forma que o discurso, quando levado a cabo, não representa o seu repetidor. A construção imagética paródica provocaria o distanciamento/estranhamento para enxergar a barbárie de contribuir com narrativas da necropolítica e até mesmo discernimento sobre quem representa ou não seus reais pensamentos, ideologias, desejos para o mundo.

"Se a alguém o próprio ato não assusta, não são palavras que vão assustar." (Édipo, de Sófocles) A criação imagética paródica afeta por outro lugar e, assim como a arte, provoca mais do que simples palavras explicam. Mesmo palavras carregadas de argumentos, legitimidade, historicidade, em tempos de pós-verdade, os recursos para o convencimento não estão na argumentação científica.

Nessa cena, as poéticas, a arte, as intervenções críticas, ocupam lugar importante para construção de contranarrativas a desobedecer às narrativas hegemônicas necro-odiosas, para criar novos significados. ${ }^{14}$ Bey (apud ZEN, 2018) sugere o termo zona autônoma temporária (TAZ) para definir esse tipo de manifestação que surge como uma ocupação de espaços por meio do discurso do contrafluxo que retém o poder de contaminar as narrativas vigentes. Para o autor, as TAZ são espaços que conquistam áreas de imaginação, emergindo e desaparecendo, cedendo lugar para novas obras, novas manifestações, "novas guerrilhas". Para exercer todo o seu potencial de espaço partilhador de experiências sociossensíveis, deve utilizar espaços/discursos assimilados pelos dispositivos de controle para problematizar novos modelos de fala que permitem o acesso a pensamentos de contra-ataque ao status quo. "Esses campos artísticos fazem emergir de forma espontânea uma voz para determinado grupo de pessoas que propõe a diversidade cultural e a individualidade como valor partilhável" (ZEN, 2018, p. 135).

\footnotetext{
${ }^{14}$ É importante salientar que o estranhamento para Lucáks não se constitui em um fenômeno natural. Ele é social, assim como a primeira percepção também é social. Essa reflexão remonta a conceitos-base da antropologia, já que estranhamento do familiar e familiarização com o estranho são essenciais para pensar o "outro". O conceito de alteridade parte da ideia de que o Eu só existe com minhas singularidades a partir do "outro". O que não reconheço em mim faz parte de mim. $\mathrm{O}$ que não sou faz parte do que sou.
}

Cadernos de estudos culturais, Campo Grande, MS, v. 2, p. 185-208, jul./dez. 2020. 
Walter Benjamin teoriza sobre o assombro ou estranhamento do teatro épico de Brecht. Benjamin (apud OLIVEIRA, 2010, n.p.) diz ser preciso "acrescentar o assombro na teoria aristotélica dos efeitos da tragédia: Quando o fluxo real da vida é represado, imobilizando-se essa interrupção é vivida como se fosse um refluxo: o assombro é esse refluxo". Lembra que, "quando perdido em um nevoeiro, pode-se 'perder-se', mas se pode também 'encontrar'". (apud OLIVEIRA, 2010, n.p.)

Essa consciência permite-lhe ordenar experimentalmente os elementos da realidade (...). Elas não são trazidas para perto do espectador, mas afastadas dele. Ele as reconhece como "condições" reais, não com arrogância, como no teatro naturalista, mas com assombro. (...) É no indivíduo que se assombra que o interesse desperta; só nele se encontra o interesse em sua forma originária (BENJAMIN, apud OLIVEIRA 2010, n.p.).

Montagnari (2010) afirma que as peças didáticas de Brecht atacam o núcleo de uma realidade que não nos permite perceber a violência de classe e, no caso da reflexão aqui proposta, a colonialidade do ser, do fazer, do sentir, de modo que acabamos por naturalizar tais violências. Bourdieu chama de violência simbólica essas violências naturalizadas na história da humanidade. Hannah Arendt de banalidade do mal. Mas usamos Brecht, com seu efeito de estranhamento ou distanciamento, já que ele propõe peças para encarar tanto o teatro quanto a vida com "estranheza". Ao estranhar algo que antes nos parecia familiar, começamos a refletir sobre. Suspeitamos que os memes da Barbie fascista provoquem esse efeito de estranhamento, já que repetem a fala de quem as pronuncia literalmente. De acordo com Patrice Pavis (apud MONTAGNARI, 2010, p. 15), o efeito de estranhamento ou distanciamento "trata-se de um procedimento estético cuja finalidade é modificar a percepção que temos de uma imagem literária, pois os objetos observados repetidas vezes, começam a ser percebidos automaticamente, deixamos de vê-lo". O autor ainda argumenta que "o procedimento da arte (...) consiste em obscurecer a forma, aumentar a dificuldade e a duração da percepção (...) criar uma visão e não o seu reconhecimento" (apud MONTAGNARI, 2010, p. 15). Os discursos colonialistas são observados repetidas vezes como o autor coloca e são automatizados, naturalizados, de forma que deixamos de vê-los. Os memes da Barbie fascista, assim como outras poéticas midiáticas, obscurecem a forma literal do discurso e dificultam a percepção da mesma frase para quem a diz. Assim, suspeitamos que possam construir um olhar, gerar sua própria narrativa, a partir da crítica humorística e paródica. 
Walter Benjamin comenta que o aumento acelerado das vivências midiáticas provocou "duas reações diferentes: a perda da experiência e a possiblidade de nova aisthesis", possibilitando o descobrir de outros caminhos. O problema aqui é "a perca (sic) da experiência individual, o não narrar, o não pensar subjetivo em razão do coletivo, o vencedor sob o vencido. A arte dos vencidos torna-se então a história dos vencedores, os filmes dos vencedores" (apud FOERSTE; CAMARGO, 2010, p. 2063). A colonialidade está fortemente presente nesse processo, de maneira que os memes críticos trazem a narrativa dos vencidos ao protagonismo da cena, provocam o pensar subjetivo, o repensar, reolhar-se. Lançam a desobediência do desvio decolonial à cena.

\section{CONSIDERAÇÕES finais}

Ter contato com situações da vida representadas por personagens parece essencial na cena política contemporânea, já que a representação poderia ser vista como estratégica para criar contranarrativas ao próprio discurso repetido. A arte é importante para vermos o que acontece conosco através do outro. Suspeita-se que o efeito de estranhamento nos memes críticos poderia afetar esses corpos falantes a experimentarem alguma possibilidade de outra perspectiva sobre seu discurso. Assim, os memes ou outras poéticas midiáticas populares, o humor, trabalhados principalmente com o recurso da paródia, da sátira, poderiam suscitar novas narrativas, espelho reverso da dramatização para afetação.

Descolonizar o olhar para o que está naturalizado na estrutura cultural é um exercício de se olhar e se estranhar constante. Os textos dos autores decoloniais contribuem para esse processo que urge na política contemporânea.

A coragem de saber e a reflexão crítica que se produz no interior das relações intersubjetivas pressupõem a possibilidade de uma prática que faz tremer a ideia de ordem (...) e inquietam definitivamente a hierarquia e os valores. (...) Obedecer, desobedecer significa sempre dar forma a uma própria liberdade. (GROS apud D’URSO, 2019, p. 258)

Poéticas midiáticas estão cada vez mais presentes no nosso imaginário, fazer uso delas para ocupar, desviar, desobedecer e criar novas perspectivas de olhar o mundo parece (parafraseando Raymond Williams) tornar a esperança possível em meio ao caos insistente. 


\section{REFERÊNCIAS}

D’URSO, Flavia. "DESOBEDECER, de Frédéric Gros". In: Polietica. São Paulo: POSFIL/PUC-SP, v.7, n.2, p. 256-261, 2019.

ECO, Umberto. O fascismo eterno. Rio de Janeiro: Editora Record, 2018.

FOERSTE, Gerda Margit Schütz; CAMARGO, Fernanda Monteiro Barreto. Estranhamento como categoria estética em arte. In: ENCONTRO DA ASSOCIAÇÃO NACIONAL DE PESQUISADORES EM ARTES PLÁSTICAS "ENTRE TERRITÓRIOS", 19., 2010, Cachoeira. Anais [...]. Cachoeira - BA: Anpap, 2010. p. 2057-2070. Disponível em: http://www.anpap.org.br/anais/2012/pdf/simposio4/gerda_foerste_e_fernanda_camargo acesso em: 29 jun. 2020.

GOMES, Renato Cordeiro. "Das margens, contranarrativas: um olhar a partir dos subúrbios do mundo". In: IPOTESI. Juiz de Fora, v.15, n.2, p. 13-19, jul./dez. 2011. Disponível em: https://www.ufjf.br/revistaipotesi/files/2011/05/6-Das-margens.pdf acesso em: 20 maio 2020.

GROS, Frédéric. DESOBEDECER, São Paulo: UBU Editora, 2018.

KOUDELA, Ingrid Dormien. Brecht: um jogo de aprendizagem. São Paulo: Ed. Perspectiva, 2010.

MBEMBE, Achille. Necropolítica: biopoder, soberania, estado de exceção, política da morte. Tradução: Renata Santini. São Paulo: N-1 edições, 2018.

MIGNOLO, Walter D. "Desobediência epistêmica: a opção descolonial e o significado de identidade em política". Tradução de Ângela Lopes Norte. In: Cadernos de Letras da UFF - Dossiê: Literatura, língua e identidade, Rio de Janeiro: UFF, n.34, p. 287-324, 2008.

MONTAGNARI, Eduardo Fernando. "Brecht: estranhamento e aprendizagem". In: Revista JIOP. Maringá: Departamento de Letras Editora, n.1, p. 9-17, 2010. Disponível em: http://www.dle.uem.br/revista_jiop_1/artigos/montagnari.pdf - acesso em: 29 jun. 2020.

OLIVEIRA, Natássia Duarte Garcia Leite de. Entre a Identificação e o Estranhamento. In: VI CONGRESSO DA ABRACE, 6., 2010, São Paulo. Anais [...]. São Paulo: Abrace, $2010 . \quad$ p. 1-5. Disponível em: https://www.publionline.iar.unicamp.br/index.php/abrace/article/view/3593. Acesso em: 14 maio 2020. 
PEREIRA, Edir. "Resistência descolonial: estratégias e táticas territoriais". In: Revista Terra Livre. São Paulo: Associação dos Geógrafos Brasileiros, ano 29, v.2, n.43, p. 1755 , 2017.

Disponível

em:

http://www.agb.org.br/publicacoes/index.php/terralivre/article/view/615/570 - acesso em: 29 jun. 2020.

QUIJANO, Aníbal. "Colonialidade do poder, eurocentrismo e América Latina". In: LANDER, Edgardo. (Org.). A colonialidade do saber: eurocentrismo e ciências sociais. $1^{a}$ ed. Buenos Aires: Consejo Latinoamericano de Ciências Sociales - CLACSO, 2005, p. 117-142.

QUIJANO, Aníbal. "Colonialidade, poder, globalização e democracia”. In: Revista Novos Rumos, Marília: Unesp, ano 17, n.37, p. 4-28, 2002. Disponível em: https://revistas.marilia.unesp.br/index.php/novosrumos/article/view/2192/1812 - acesso em: 29 jun. 2020.

RODRIGUES, Márcia Regina. Traços épico-brechtianos na dramaturgia portuguesa: $O$ render dos heróis de Cardoso Pires e Felizmente há luar! de Sttau Monteiro. 2010. 110 f. Dissertação (Mestrado em Estudos Literários) - Universidade Estadual Paulista Júlio de Mesquisa Filho - Unesp, Araraquara, 2010. Disponível em: https://repositorio.unesp.br/handle/11449/99178 - acesso em: 20 jun. 2020.

SAFERLAB. TOOL BOX Crie sua contranarrativa. Disponível em: http://saferlab.org.br/guia.pdf - acesso em: 19 jun. 2020.

SOUZA, Gabriela Neves Paula de. O cidadão modelo pós eleição de 2018 no Brasil: colonialidade no discurso dos representantes do estado. In: COLÓQUIO INTERNACIONAL: RACISMO AMBIENTAL, EDUCAÇÃO E INTERCULTURALIDADE, 1, 2019. Anais [...]. Rondonópolis - MT: UFMT. p. 1-15. Disponível em: https//www.even3.com.br/anais/1coloquioracismo/173213-o-cidadaomodelo-pos-eleicao-de-2018-no-brasil--colonialidade-no-discurso-dos-representantes-doestado - acesso em: 14 maio 2020.

SÉKULA, Ricardo José. Os memes como exercício de contrapoder a discursos políticomidiáticos: Uma reflexão a partir dos debates eleitorais de 2014. 2016. 238 p. Dissertação (Mestrado em Comunicação) - Universidade Federal de Santa Catarina, Florianópolis, $2016 . \quad$ Disponível em: https://repositorio.ufsc.br/xmlui/handle/123456789/174914 - acesso em: 29 jun. 2020.

ZEN, Rafael Luiz. "A supressão do outro no episódio do queermuseu: a liberdade de expressão sob coerção e o que pode o artivismo queer”. In: Palíndromo, v.10 n.21, p. 130-154, 2018. Disponível em:

https://www.revistas.udesc.br/index.php/palindromo/article/view/12286 - acesso em: 10 out. 2019. 
Artigo recebido em: 30 de setembro de 2020 . Artigo Aprovado em: 29 de novembro de 2020. 